\title{
Projet-Based Learning: Terobosan Baru dalam Melatih HOTS pada Keterampilan Speaking Mahasiswa
}

\author{
Ridwan Yasin Setiawan ${ }^{(1)}$, Romadela Dwi Puspitasari(2), Giga Baptista ${ }^{(3)}$ \\ Universitas Nusantara PGRI Kediri, Indonesia \\ Email: ${ }^{1}$ ridwansetiawan68@ gmail.com, ${ }^{2}$ romadilla@gmail.com, \\ ${ }^{3}$ gigabaptista@gmail.com
}

\begin{tabular}{l}
\hline Tersedia Online di \\
http://www.jurnal.unublitar.ac.id/ \\
index.php/briliant
\end{tabular}

Sejarah Artikel

Diterima pada 7 September 2020

Disetujui pada 13 November

2020

Dipublikasikan pada 30

November 2020

Hal. 721-730

\section{Kata Kunci: \\ Project Based Learning; HOTS; Speaking}

\section{DOI:}

http://dx.doi.org/10.28926/briliant .v3i4.542

\begin{abstract}
Abstrak: Di era revolusi industri 4.0, mahasiswa dituntut memiliki keterampilan berpikir tingkat tinggi (High Order Thingking Skills). Projet-Based Learning (PjBL) adalah model pembelajaran yang telah terintregasi dengan HOTS. Kemampuan HOTS mencakup tiga aspek, yaitu kemampuan menganalisis, mengevaluasi, dan berkreasi. Tujuan penelitian ini adalah mendeskripsikan langkah-langkah dalam PjBL pada mata kuliah Speaking for Informal Communication dan proses penanaman HOTS mahasiswa menggunakan model pembelajaran $\mathrm{PjBL}$ pada mata kuliah Speaking for Informal Communication di UNP Kediri. Penelitian ini adalah studi kasus dengan menggunakan pendekatan deskriptif kualitatif. Peneliti menggunakan 3 teknik untuk mengumpulkan data yang meliputi observasi, wawancara, dan dokumen analisis. Hasil penelitian ini menunjukan proses melatih HOTS mahasiswa yang terintegrasi dalam 4 langkah PjBL, yaitu Persiapan, Pelaksanaan, Pengembangan, dan Penyajian.
\end{abstract}

\section{PENDAHULUAN}

Di era revolusi industri, perubahan teknologi memberikan efek besar terhadap dunia industri dan pola kehidupan masyarakat. Zubaidah (2018) menyatakan bahwa adanya perkembangan teknologi menjadikan banyak jenis pekerjaan baru muncul sesuai dengan dunia industri butuhkan seperti blogger, aps developer, copy writer, graphic desaigner, web developer, content creator, dan lain sebagainya. Hal ini menjadikan tantangan bagi generasi muda untuk meningkatan kualitas sumber daya manusia agar mampu beradaptasi dengan perubahan yang terjadi. Berdasarkan survei World Economic Forum (WEF) terhadap 186 negara, bahwa terdapat 50\% penduduk dunia saat ini berusia 30 tahun, Zubaidah (2020) menyatakan bahwa adanya perkembangan teknologi menjadikan persaingan dalam dunia kerja sangat ketat, salah satu cara yang dapat dilakukan dengan menyiapkan kompetensi generasi muda. Hal ini di dukung oleh pendapat Hendayana (2020) bahwa kondisi saat ini dikenal dengan VUCA atau vulnerable, uncertain, complex, dan ambiguity sehingga dibutuhkan kompetensi bagi tiap individu untuk bisa berpikir kritis dan menjadi pemecah masalah atau high order thinking skills (HOTS).

Di era ini, perkembangan teknologi juga sangat berpengaruh pada dunia pendidikan. Kondisi ini menjadi tantangan global untuk meningkatkan kualitas 
sumber daya manusia penyelenggara pendidikan, terutama guru dan siswa. Guru sebagai orang yang memberikan pengalaman belajar, sedangkan siswa adalah subyek yang belajar. Untuk itu guru harus membekali siswa sejumlah keterampilan dan kompetensi agar mereka mampu bersaing seara global. Keterampilan yang dimaksud adalah keterampilan 4C (Collaborative, Critical, Creative, and Communicative), atau keterampilan berkolaboratif, keterampilan berpikir kritis, keterampilan berkreasi serta keterampilan berkomunikasi.

Salah satu keterampilan keterampilan yang penting alam era saat ini adalah keterampilan berpikir kritis. Facione dan Sachez (2010:197) berpendapat bahwa kemampuan berpikir kritis adalah sebuah proses pengambilan keputusan berdasarkan pertimbangan bukti yang ada serta aspek kontekstual dalam sebuah situasi. Kemampuan ini merangsang siswa untuk memiliki kemampuan berpikir tingkat tinggi (High Order Thingking Skills selanjutnya ditulis HOTS). Dengan demikian, siswa harus dilatih agar mampu melihat suatu masalah atau fenomena yang dihadapi dari berbagai sudut pandang sehingga mereka dapat membuat suatu keputusan yang tepat untuk melakukan tindakan.

HOTS merupakan kemampuan berpikir kritis, logis, reflektif, metakognitif, dan berpikir kreatif yang merupakan kemampuan berpikir tingkat tinggi. Resnick (1987) mendefinisikan High Order Thinking Skill (HOTS) adalah proses berfikir kompleks dalam menguraikan materi, membuat kesimpulan, membangun representasi, menganalisis, dan membangun hubungan dengan melibatkan aktivitas mental yang paling dasar. Untuk bisa memiliki keterampilan berpikir tingkat tinggi, siswa harus memiliki tiga keterampilan dalam HOTS sesuai dengan Taxonomy Bloom, yakni analisis, evaluasi, dan mencipta (cretaing). Sebagian besar penelitian yang ditemukan belum mengarahkan pada level mencipa (cretaing). Selanjutnya, Karthwoll (2002) yang membagi 3 tahapan dalam proses HOTS yaitu kemampuan menganalisis (analyzing), kemampuan mengevaluasi (evaluating), dan kemampuan berkreasi (creating). Melalui tahapan tersebut siswa dipersiapkan untuk menjadi pemecah masalah yang baik (problem solver) dan mampu membuat keputusan (decision maker) maupun kesimpulan yang matang dapat dipertanggungjawabkan.

Kenyataan di lapangan, banyak dijumpai proses pembelajaran dikelas yang masih monoton. Guru sekedar menjelaskan materi di papan tulis kemudian siswa mencatat dan menghafal materinya. Selain itu, guru hanya meminta siswa mengerjakan latihan soal yang ada di buku pedoman. Trihanifa (2013) menyatakan, "Proses pembelajaran yang mototon yang hanya menempatkan siswa sebagai subyek belajar akan menghambat proses berpikir kreatif siswa dan tidak memberi kesempatan siswa untuk berpikir kritis dalam memecahkan masalah." Idealnya, guru memberikan berbagai kegiatan yang dapat melatih HOTS siswa. Oleh karena itu, proses pembelajaran harus berpusat pada siswa (student centered learning) agar mereka belajar untuk menganalisis, mengevaluasi, dan memutuskan suatu masalah. Dengan demikian, proses pembelajaran yang berpusat pada siswa melibatkan siswa secara langsung dalam membangun pengetahuan, sikap, dan keterampilan bagi mereka.

Pidato Menteri Pendidikan dan Kebudayaan Nadiem Makarim pada peringatan hari guru (2019) menegaskan bahwa pendidik harus memberikan kesempatan dan ruang bagi setiap siswa untuk berani mengemukakan ide atau gagasan mereka dan memberikan kesempatan bagi siswa untuk mengajar. Dari apa

722 BRILIANT: Jurnal Riset dan Konseptual

Volume 5 Nomor 4, November 2020 
yang disampaikan mendikbud di atas, diharapkan siswa seharusnya diberi kesempatan untuk menyampaikan gagasan, sedangkan guru memberi ruang bagi mereka untuk berkreasi. Dengan demikian, guru melatih HOTS siswa dalam proses pembelajaran karena siswa diberikan ruang kebebasan untuk belajar secara mandiri dan kreatif.

Permasalahan yang muncul adalah tidak semua guru atau dosen melatih keterampilan HOTS mahasiswa. Mereka lebih sering memberikan pengalaman belajar yang menekankan aspek penalaran. Menurut pengalaman peneliti, dosen lebih sering menugasi mahasiswa untuk memahami suatu materi, dan diakhiri tugas untuk merangkum. Hal ini juga didukung oleh pengamatan dari penelitian Muspawi, Suratno, \& Ridwan (2014) bahwa guru atau dosen kurang memberikan kesempatan bagi siswa untuk melatih kemmapuan berpikir kritis karena model pembelajaran yang digunakan masih menggunakan metode pembelajaran konvensional yaitu dengan cara menghafal dan menerima informasi saja, menggunakan metode ceramah yang disampaikan di depan kelas. Sehingga guru atau dosen kurang berinovatif dalam mengembangkan proses pembelajaran dalam melibatkan mahasiswa yang lebih aktif belajar. Hal itu tentu saja belum cukup melatih HOTS mahasiswa.

Permasalahan itu berdampak pada mahasiswa yang kurang menyadari penting memiliki keterampilan HOTS pada diri mereka. Sehingga masih dijumpai mahasiswa kurang kritis, inovatif dan kreatif dalam menghadapi suatu masalah sehingga mereka cenderung menyalahkan kelemahan diri dan mudah menyerah. Untuk itu diperlukan terobosan baru dalam melatih HOTS mahasiswa.

Salah satu terobosan dalam melatih HOTS adalah menggunakan model pembelajaran Projet Based Learning (PjBL). PjBL adalah model pembelajaran berbasis proyek dimana siswa diharuskan membuat produk atau karya pada tahap akhir pembelajaran. Manahal (2009) mendefinisikan PjBL adalah pembelajaran dengan menggunakan proyek sebagai metode pembelajaran. Para siswa bekerja secara nyata, seolah-olah ada di dunia nyata yang dapat menghasilkan produk secara realistis. Sedangkan Bell (2010) berpendapat bahwa PjBL merupakan model pembelajaran yang inovatif melalui proses inkuiri dan kolaborasi dalam memecahkan masalah untuk menghasilkan produk berdasarkan ilmu yang dimilikinya. Oleh karena itu model pembelajaran ini dirasa sangat sesuai untuk melatih HOTS mahasiswa.

Ada berbagai tahapan dalam PjBL, yang salah satunya yang disampaikan oleh Nurhajati (2020). Tahapan yang dimaksud adalah Persiapan (preparation), Pelaksanaan di kelas (implementation), Pengembangan (developing), and Penyajian (presenting). Pada tahap Persiapan guru memilih materi yang sesuai dengan kompetensi yang ingin dicapai dan merencanakan proyek yang akan dibuat oleh siswa. Pada tahapan Pelaksanaan guru menyampaikan tujuan pembelajaran dan mendiskusikan dengan siswa proyek yang akan dibuat. Selanjutnya siswa mulai merancang proyek atau produk secara berkelompok. Selanjutnya pada tahap Pengembangan, siswa membuat produk atau proyek berdasarkan materi dan tema yang telah dipilih. Sedangkan pada tahap Penyajian, siswa menyajikan proyek atau produk yang telah dibuat. Dengan demikian PjBL dirancang untuk digunakan pada permasalahan komplek yang diperlukan siswa dalam melakukan insvestigasi dan memahaminya. 
Beberapa penelitian terdahulu menemukan bahwa PjBL dapat melatih berbagai keterampilan siswa. Pertama, hasil penelitian dari Ravitz, Hixson, English, \& Mergendoller (2012) menyatakan bahwa penggunaan model pembelajaran PjBL dapat melatih keterampilan abad 21 seperti kolaborasi, berpikir kritis, kreativitas, komunikasi, dan keterampilan penggunaan teknologi. Penerapan $\mathrm{PjBL}$ dalam proses pembelajaran dengan efektif dapat berpengaruh dalam keterampilan abad 21. Selanjutnya, berdasarkan hasil penelitian yang dilakukan oleh Nurhajati (2018) menemukan bahwa dengan PjBL mahasiswa belajar banyak life skills melalui pembuatan proyek yang berupa Video Blog (Vlog). Para mahasiswa berlatih berpikir kritis, terbuka, menjalin komunikasi dengan sesama, berinisiatif, berkreasi, dan memiliki rasa percaya diri. Selain itu, hasil penelitian Aghayani \& Hajmohammadi (2019) yang meneliti pembelajaran keterampilan menulis, menyatakan bahwa PjBL berpengaruh signifikan terhadap tulisan peserta didik. Siswa mampu meningkatkan kemampuan menulis mereka dalam keterampilan kolaboratif dengan lingkungan. Sementara penelitian yang dilakukan oleh Nurhajati, Kencanawati, \& Riwayatiningsih (2020) menyatakan bahwa melalui penerapan model pembelajaran $\mathrm{PjBL}$ dalam pembelajaran Speaking dapat meningkatkan kemampuan berpikir kritis siswa. Siswa dapat mengidentifikasi masalah dari topik proyek yang diberikan pada Speaking skills, menguraikan masalah atau menganalisis masalah, kemudian siswa dapat mengevaluasi masalah dengan berbagai pertimbangan kelebihan dan kekurangan, kemudin dari pertimbangan-pertimbangan yang dilakukan siswa dapat memutuskan berkreasi dengan memilih proyek yang ditampilkan.

Selanjutnya, beberapa penelitian menunjukkan bahwa guru atau dosen dapat melakukan berbagai cara menanamkan HOTS. Pertama, Lee \& Lai (2017) menegaskan bahwa HOTS dapat diimplementasikan melalui model pembelajaran flipped classroom dengan melihat hasil tugas yang diberikan oleh guru berupa proyek. Namun, dalam penelitian ini belum mengungkapkan bagaimana proses penanaman HOTS yang dilakukan oleh guru dengan menggunakan model pembelajaran flipped classroom. Penelitian lain, yang dilakukan oleh Indriyana \& Kuswandono (2019), mengungkapkan bahwa penanaman HOTS dalam reading skills masih dalam tahap guru menginformasikan tujuan pembelajaran. Selain itu, penggunaan HOTS dalam reading skills untuk meningkatkan kemampuan berpikir kritis siswa dalam memahami konteks materi pembelajaran melalui diskusi kelompok dan memberikan feedback untuk memotivasi siswa dalam berpikir kritis. Ketiga, Yulia dan Budiharti (2019) menemukan bahwa penanaman HOTS dapat dilakukan melalui interaksi guru dengan siswa saat proses pembelajaran. 20 - 40\% interaksi guru dengan siswa yaitu pertanyaan.

Berdasarkan uraian di atas, penelitian ini dirasa sangat penting dilakukan untuk mendiskripsikan bagaimana guru menanamkan HOTS dalam pembelajaran Bahasa Inggris, khususnya keterampilan berbicara. Penelitian yang dilaksanakan di Universitas Nusantara PGRI Kediri (UNP) ini bertujuan untuk menjawab pertanyaan bagaimana langkah-langkah model pembelajaran PJBL pada mata kuliah Speaking for Informal Communication di UNP Kediri? Dan bagaimanakah proses pelatihan HOTS mahasiswa UNP Kediri dalam proses pembelajaran Speaking for Informal Communication yang menggunakan model PjBL?

\section{METODE}

724 BRILIANT: Jurnal Riset dan Konseptual

Volume 5 Nomor 4, November 2020 
Penelitian ini merupakan studi kasus dengan menggunakan pendekatan deskriptif kualitatif. Fokus penelitian ini adalah bagaimana proses pembelajaran dalam mata kuliah Speaking for Informal Communication menggunakan PjBL oleh dosen. Subyek yang diteliti adalah dosen pengampu mata kuliah Speaking for Informal Communication dan mahasiswa yang menempuh mata kuliah tersebut. Sedangkan waktu penelitian ini dilaksanakan selama 4 bulan, dimulai pada bulan September hingga Desember 2019.

Peneliti menggunakan tiga teknik dalam mengumpulkan data yaitu observasi, wawancara dan dokumentasi. Pada tahap observasi peneliti melihat langsung proses pelaksanaan pembelajaran menggunakan model pembelajaran PjBL pada mata kuliah Speaking for Informal Communication. Peneliti menggunakan field-note untuk menuliskan fenomena yang terjadi di dalam kelas. Teknik wawancara digunakan untuk melengkapi data atau informasi yang kurang lengkap selama proses observasi. Subyek yang diwawancari adalah dosen pengampu mata kuliah tersebut dan tiga mahasiswa. Selain itu peneliti memperoleh data dari dokumen yang berupa Rencana Perkuliahan Semester (RPS) mata kuliah Speaking for Informal Communication dan Vlog yang telah dibuat oleh siswa.

\section{HASIL}

Mata kuliah Speaking for Informal Communication adalah salah satu mata kuliah di Program Studi Pendidikan Bahasa Inggris, UNP Kediri. Tujuan Pembelajaran dari mata kuliah ini adalah di akhir pembelajaran mahasiswa mampu berkomunikasi Bahasa Inggris secara lisan sesuai dengan materi yang tercantum pada mata kuliah Speaking for Informal Communication.

\section{a. Persiapan (Preparation)}

Pada tahap ini, dosen merumuskan tujuan pembelajaran dan proyek yang akan dibuat oleh mahasiswa. Selanjutnya dosen menyampaikan tujuan pembelajaran dan mendiskusikan proyek yang akan dibuat pada akhir pmbelajaran. Dari hasil diskusi disepakati mahasiswa membuat proyek berupa Vlog. Isi dari Vlog tersebut adalah materi yang tercantum dalam RPS dari mata kuliah Speaking for Informal Communication seperti Pengenalan Diri (Introduction), Cara Menyampaikan Petunjuk Arah (Direction), Deskripsi dari Suatu Object (Description of object), dan Menyampaikan Pendapat (Giving Opinion).

Sementara pada tahap ini, mahasiswa berdiskusi dengan kelompoknya untuk merencanakan topik apa yang akan diangkat dalam Vlog mereka dan mencari referensi yang dapat digunakan untuk model proyek mereka.

\section{b. Pelaksanaan (Implementation)}

Pada tahap ini, mahasiswa menyusun strategi bagaimana merealisasikan karya yang berupa Vlog yang akan dibuat dimulai dari segi konsep serta konten yang diangkat, objek yang dipilih, bahasa yang digunakan dalam Vlog, dan urutan penyampaian informasi dalam Vlog. Selain itu, mahasiswa juga berlatih bagaimana ekpresi dan gaya penyampian mereka saat berbicara.

\section{c. Pengembangan (Developing)}

Pada tahap ini, mahasiswa melakukan pengambilan video dan gambar. Setelah itu, mereka melakukan editing video dengan menambah teks, atau mengurangi gambar agar hasil proyek Vlog menarik untuk diunggah di laman YouTube. Mereka juga menambahkan instrumen musik sebagai latar video 
mereka. Semua kegiatan ini dilakukan di luar kelas. Di dalam proses pembelajaran di kelas, mereka berlatih berbicara Bahasa Inggris sesuai dengan target materi yang tertulis di dalam Rencana Pembelajaran Semester.

\section{d. Penyajian (Presenting)}

Pada tahap ini, mahasiwa melakukan publikasi proyek Vlog melalui laman YouTube. Namun sebelum mereka menggunggah video mereka, mahasiswa menyajikan karyanya di kelas untuk memperoleh masukan baik dari dosen maupun teman sejawat agar Vlog yang akan diunggah hasilnya lebih baik.

Dalam membuat Vlog melalui tahapan-tahapan PjBL, mahasiswa secara bertahap melatih keterampilan berpikir tingkat tinggi (HOTS). Keterampilan yang dilatih meliputi kemapuan menganilisis suatu permasalahan (Analyzing), mengevaluasi dengan berbagai pertimbangan yang diambil (Evaluating), memutuskan tindakan atau strategi yang diambil dari masalah (Creating). Setelah menciptakan strategi yang diambil mahasiswa dalam mereasilasikan proyek yang berupa Vlog yang akan diunggah di kanal YouTube. Adapun proses latihan HOTS mahasiswa dapat dijelaskan sebagai berikut:

Pertama, latihan keterampilan menganalisis (analyzing) dapat diperoleh pada tahap perencanaan (Planning). Pada tahap ini mahasiswa memperoleh gambaran dari contoh video yang diberikan oleh dosen, dan berdasarkan contoh yang diberikan mereka menentukan topik. Topik yang disepakati dosen pengampu dan mahasiswa adalah hal-hal yang berhubungan dengan keraifan lokal (local wisdom) yang ada di Kediri. Misalnya, makanan tradisional yang berasal dari Kediri (Pecel, Gethuk Pisang, Tahu Takwa, dan sebagainya), tempat wisata Kediri (Goa Selomangleng, Gunung Kelud, Air Terjun Dolo, dan sebagainya), kerajinan tangan Kediri (Kain Tenun Bandar Kediri, Kerajinan Rotan Sintesis, Kerajinan Tangan Limbah Kayu, dan sebagainya), dan Kampung Inggris Pare. Mahasiswa boleh memilih topik lain yang mereka suka atau minati. Pada tahap ini, mahasiswa mulai berlatih membuat keputuasan. Untuk itu, mereka harus berpikir kritis, selfawarness, dan kreatif dari topik, konsep, desain, dan hal lainnya sesuai yang diangkat dalam Vlog.

Kedua, keterampilan evaluasi (evaluating) tercermin pada tahap punyusunan proyek, mahasiswa mulai mempertimbangkan beberapa resiko sebelum memutuskan semua rancangan konsep Vlog yang akan dibuat dimulai dari segi konten Vlog, pengambilan video dan gambar, tahapan penyajian informasi dalam Vlog, edit Vlog, gaya bahasa, gaya penampilan, dan lain sebagainya. Mereka merancang keseluruhan kebutuhan untuk proyek Vlog ini dengan berbagai pertimbangan dan keputusan yang beresiko kecil. Pada tahap ini, mahasiswa menganilisis topik apa yang sesuai dengan minat dan ketertarikan mereka terhadap suatu objek. Sebagai contoh, ada mahasiswa yang memutuskan untuk mengambil topik tempat wisata Goa Selomangleng dengan alasan lokasinya mudah diakses, selain ingin memperknalkan tempat wisata Kediri yang belum banyak dikenal oleh orang luar Kediri. Dengan membuat Vlog ini, mahasiswa ingin memperkenalkan tempat wisata Kediri melalui sosial media. Selain itu, ada satu mahasiswa yang memilih topik makanan tradisional, yaitu Pecel Kediri. Alasannya, makanan ini mudah dijumpai di Kediri dan ingin menjelaskan perbedaan makanan tradisional khas Kediri ini dengan yang dari luar Kediri kepada khalayak luas. Contoh lain, ada mahasiswa yang memilih topik tari modern, dengan alasan menari adalah hobinya,

726 BRILIANT: Jurnal Riset dan Konseptual

Volume 5 Nomor 4, November 2020 
dia adalah instruktur tari, dan dia ingin memberikan pandangan lain (new insight) terhadap tari modern untuk terapi kebahagian. Pada tahap ini, mahasiswa berlatih untuk berpikir kritis dan kreatif dalam meongorganisir rencana proyek Vlog melalui proses HOTS.

Ketiga, keterampilan berkreasi (creating) terecermin pada tahap pelaksanan dan publishing karya Vlog mereka. Pada tahap ini, mahasiswa melakukan rencanarencana yang telah dibuat pada tahap sebelumnya. Pada tahap ini, mahasiswa berlatih berbicara bahasa Inggris sesuai dengan topik yang diangkat. Mahasiswa mempertimbangkan gaya bahasa yang dipakai sesuai dengan audien yang menjadi target mereka. Kemampuan berkomunikasi oleh mahasiswa tampak dalam Vlog tersebut bagaimana mereka memberikan informasi dan mendeskripsikan suatu objek dengan penyampaian yang jelas dan mudah di pahami oleh penonton. Selain itu, mahasiswa secara tidak langsung juga melatih rasa percaya diri pada saat berbicara di depan kamera karena tidak mudah bagi mahasiswa untuk berbicara Bahasa Inggris di depan kamera. Kemudian mahasiswa melakukan proses edit Video yang telah mereka rekam. Untuk mendapatkan hasil Vlog yang bagus dan menarik, mereka berlatih untuk mengedit video dari berbagai sumber seperti youtube dan internet. Beberapa mahasiswa meminta bantuan kepada teman yang lebih paham dalam bidang edit video ketika mendapat kesulitan saat proses edit video. Hal ini, mereka berlatih keterampilan (skills) lain dalam bidang edit video yang sebelumnya tidak didapatkan dalam perkuliahan. Mereka juga berlatih untuk kreatif dan bekerja sama dengan teman ketika mendapatkan kesulitan saat proses edit video.

Kemudian mahasiswa mempresentasikan draft Vlog di kelas untuk mendapatkan masukan dari dosen dan teman sekelas mereka sebelum diunggah di kanal Youtube. Mahasiswa berlatih untuk berpikir terbuka atau mempunyai pola pikir bertumbuh (Growth mindset) yang mana mahasiswa percaya bahwa masukan, kritik, ataupun komentar dari dosen atau teman sekelas terhadap Vlog yang ia buat untuk membuat hasil proyek Vlog mereka lebih baik dan lebih bagus. Dari masukan yang diberikan, mahasiswa berlatih untuk mengevaluasi, memperbaiki, dan mengkreasikan hasil Vlog mereka agar lebih bagus lagi bukan sebagai intimidasi atas karya yang telah ia buat. Pada tahap ini, mahasiswa berlatih untuk mempunyai pikiran terbuka dan menerima masukan sebagai proses untuk memperbaiki karya Vlog mereka.

Pada tahap publikasi (publishing) Vlog di kanal Youtube, mahasiswa menentukan strategi bagaimana agar Vlog yang mereka buat dapat dijangkau dengan mudah oleh orang lain. Sebagian dari mahasiswa memutuskan untuk memberikan tagar (Hashtag) dalam kolom deskripsi di Youtube. Selain itu, orang lain yang menonton Vlog mereka dapat memberikan komentar maupun masukan terhadap Vlog mereka. Sehingga, mereka dapat melakukan evaluasi dari apa yang telah mereka buat. Hal ini, mahasiswa memiliki kemampuan berpikir kritis dan networking dalam memutuskan untuk memberikan tagar (Hastag) dalam pengunggahan Vlog mereka agar dapat dengan mudah dijangkau oleh penonton.

\section{PEMBAHASAN}

Jika dibandingkan dengan beberapa penelitian terdahulu, ada beberapa kesamaan dan perbedaan pada temuan penelitian ini. Persamaan temuan penelitian ini dengan beberapa penelitian terdahulu adalah penelitian yang menfokuskan pada 
penerapan pembelajaran yang menggunakan PjBL (Nurhajati (2016), Kavlu (2017), Aghayani \& Hajmohammadi (2019), dan Setiawan \& Nurhajati (2019). Namun setiap penelitian memiliki perbedaan yaitu penerapan $\mathrm{PjBL}$ pada keterampilan Bahasa Inggris atau mata kuliah dan subyek yang diteliti. Misalnya Nurhajati (2016) dan Aghayani \& Hajmohammadi (2019) meneliti Project Based Learning untuk meningkatkan keterampilan menulis pada siswa SMP, sedangkan Kavlu (2017) meneliti penerapan Project Based Learning pada mata kuliah English for Foreign Language. Namun penelitian tersebut masih belum meneliti HOTS dalam pembelajaran Bahasa Inggris baik di tingkat sekolah menengah maupun di perguruan tinggi. Penelitian-penelitian terdahulu lebih menekankan pada hasil belajar siswa.

Jika dibandingkan dengan penelitian terdahulu, penelitian ini memiliki beberapa kesamaan. Persamaan yang paling menonjol adalah bahwa PjBL adalah model pembelajaran yang tepat untuk digunakan dalam mengajar writing skills Aghayani \& Hajmohammadi (2019) khususnya membantu siswa mengembangkan ide melalui keterampilan kolaboratif dengan lingkungan. Selain itu, PjBL tidak hanya meningkatkan kemampuan berbahasa mahasiswa tetapi juga mampu meningkatkan kemampuan mahasiswa dalam menganalisis dan memecahkan permasalahan yang kompleks seperti kemampuan berfikir kritis dan menganalisis masalah (Aghayani \& Hajmohammadi 2019). Sementara Setiawan \& Nurhajati (2019) dalam penelitiannya menunjukkan bahwa menggunakan model pembelajaran $\mathrm{PjBL}$ yang mana tujuan akhir pembelajaran yaitu mahasiswa membuat Vlog melalui tahapan-tahapan PjBL, yakni: tahap speculation, tahap designing project, tahap conducting project, dan tahap evaluation. Melalui tahapantahapan PjBL tersebut, dosen menanamkan life skills mahasiswa yang meliputi berpikir kritis, kreatif, mengenali potensi diri \& lingkungan, mandiri, kerjasama, networking, percaya diri, dan communication skills. Hasil dari penanaman life skill mahasiswa dapat dilihat dari hasil Vlog yang telah dibuat oleh mahasiswa. Berdasarkan penelitian tersebut, $\mathrm{PjBL}$ terbukti dapat digunakan untuk menanamkan life skills mahasiswa dalam meningkatkan kemampuan berbicara bahasa Inggris. Sementara Nurhajati (2017) juga menunjukkan bahwa selama proses pembelajaran karakter siswa akan terbentuk melalui tahapan PjBL dimana hasil akhir siswa harus mampu membuat buku bahasa Inggris. Selanjutnya, penelitian dilakukan oleh Sholikah (2019) bahwa model pembelajaran PjBL berpengaruh pada speaking skills dan kemampuan berpikir kritis siswa. Hal ini dibuktikan dengan nilai yang di dapat siswa setelah menggunakan PjBL meningkat. Penelitian yang terakhir, memiliki persamaan, yaitu kearah berfikir kritis, namun masih belum meniliti HOTS.

Dari hasil pembahasan di atas, dapat disimpulkan bahwa PjBL adalah salah satu model pembelajaran inovatif yang mampu menanamkan life skills mahasiswa. Selain itu keterampilan berfikir tingkat tinggi (HOTS) dapat di integrasikan melalui tahapan-tahapan dalam model pembelajaran Project Based Learning (PjBL). Melalui tahapan-tahapan $\mathrm{PjBL}$ dosen melatih HOTS pada mahasiswa yang mana mahasiswa dapat memperoleh keterampilan menganalisis (analyzing) suatu objek dari beberapa sudut pandang, mengevaluasi (evaluating) objek dengan memprtimbangkan kelebihan dan kekurangan beberapa objek, dan berkreasi (creating) memtuskan masalah dengan alasan yang tepat. Sehingga mereka dapat menjadi pengambil keputusan (decision maker) dan pemecah masalah (problem solver) dari masalah yang dialami dalam kehidupan sehari-hari. Sehingga

728 BRILIANT: Jurnal Riset dan Konseptual Volume 5 Nomor 4, November 2020 
penelitian ini memfokuskan bagaimana HOTS dilatihkan melalui penerapan model pembelajaran PjBL.

\section{KESIMPULAN}

Temuan penelitian ini adalah terobosan yang dilakukan oleh dosen pengampun mata kuliah Speaking for Informal Communication untuk melatih keterampilan berfikir kritis (HOTS) mahasiswa. Pertama, capaian pembelajaran mata kuliah itu adalah mahasiswa mampu mengungkapakan berbagai informasi dalam Bahasa Inggris yang berterima dalam Vlog yang diunggah di kanal YouTube. Kedua, melalui model pembelajaran PjBL mahasiswa dilatih keterampilan berfikir kritis karena mereka harus membuat proyek yang melalui beberapa tahapan: Persiapan (preparation), Pelaksanaan di kelas (implementation), Pengembangan (developing), dan Penyajian (presenting). Dengan demikian, melalui langkahlangkah dalam PjBL siswa dilatih untuk mampu menganaslis suatu masalah atau fenomena suatu objek, kemudian mengevaluasi dengan mempertimbangkan kelebihan dan kekurangan objek dan memutuskan suatu masalah dengan pertimbangan yang tepat. Sehingga mereka mampu menjadi pemecah masalah (problem solver) sekaligus pembuat keputusan (decision maker) yang baik dengan menjadikan HOTS sebagai bagian dari lifestyle mereka di Era Revolusi Industri 4.0.

\section{SARAN}

Berdasarkan hasil penelitian, peneliti merekomendasikan kepada guruguru maupun dosen untuk menerapkan model pembelajaran $\mathrm{PjBL}$ sebagai upaya melatih keterampilan berfikir kristis (maha)siswa. Guru atau dosen dapat menentukan proyek atau karya yang akan dibuat (maha)siswa dengan cara berdiskusi bersama. Karya yang dibuat sebaiknya yang aplikatif yang dapat dijumpai dalam kehidupan mereka.

\section{DAFTAR RUJUKAN}

Aghayani, H. \& Hajmohammadi, E. 2019. Project-Based Learning: Promoting Efl Learners' Writing Skills. Journal: A Journal on Language and Language Teaching. Volume 22:78.

Bell, S. 2010. Project-Based Learning for the 21st Century: Skills for the Future.Taylor \& Francis Group, LLC.

Creswell, J. W. 2010. Educational Research: Planning, Conducting, and Evaluating Quantitative and QualitativeResearch. Boston: Pearson

Facione, P. A., Sánchez, C. A., Facione, N. C., \& Gainen, J. 2010. The disposition toward critical thinking. Journal of General Education. 44 (1), 1-25.

Hendayana, Y. 2020. Keterampilan Pada Abad-21 Disiapkan Untuk Sambut Bonus Demografi Indonesia. Kemendikbud News, 25 Oktober 2020. Jakarta.

Indriyana, B. S. \& Kuswandono, P. 2019. Developing Student's Higher Order Thinking Skills (HOTS) in Reading : English Teacher's Strategies in Selected Junior High School. Journal of English Teaching, 5(3) 204-216

Kavlu, A. 2017. Implementation of Project Based Learning (PBL) in EFL (English as a Foreign Language) Classrooms in Fezalar Educational Institutions. International Journal of Social Sciences \& Educational Studies. Volume $4(2) 67-69$ 
Krathwohl, R. D. 2002. A Revision of Bloom's Taxonomy: An Overview. Journal Theory into Practice. Volume 41(4), 212-218

Lee, K. Y \& Lai, Y. C. 2017. Facilitating Higher-Order Thinking with The Flipped Classroom Model: A Student Teacher's Experience in A Hong Kong Secondary School. Research and Practice in Technology Enhanced Learning, 12(8) 1-14

Muspawi, M., Suratno, Ridwan. 2014. Upaya Peningkatan Higher Order Thinking Skills (HOTS) Siswa Melalui Penerapan Model Inquiri di SMA Negeri 9 Tanjung Jabung Timur. Jurnal Ilmiah Universitas Batanghari Jambi, 19(2) 208-214

Nurhajati, D., \& Widiarini. 2016. Developing an Instructional Guideline Using Project Based Learning to Teach Speaking to Junior High School Students. The $5^{\text {th }}$ ELTLT International Conference Proceedings. 8-9 Oktober 2016, Semarang Indonesia. Pp 143-148

Nurhajati, D. 2017. Creating English Student Book Through Project-Based Learning in TEYL Subject. In International conference on English Language Teaching (ICONELT). Atlantis Press

Nurhajati, D. 2018. Creating Vlog As The Learning Outcome To Teach Speaking. The $12^{\text {th }}$ Bicole International Conference Proceedings. 23-25 July 2018, Bandung, Indonesia. pp 1-7

Nurhajati, D., \& Kencanawati, D., \& Riwayatiningsih, R.. 2020. Enhancing Critical Thinking in Speaking Skill through Sekawan. English Education: Journal of English Teaching and Research. Volume 5(1) 92-102.

Ravitz, J., Hixson, N., English, M., \& Mergendoller, J. 2012. Using Project Based Learning to Teach $21^{\text {st }}$ Century : Finding From A Statewide Initiative. In American Educational Research Association Conference, Vancouver, Canada (Vol. 16).

Setiawan, R.Y., \& Nurhajati, D. 2019. Project-Based Learning: Solusi Jitu Menanamkan Life Skill Mahasiswa UNP Kediri. Prosiding SEMDIKJAR (Seminar Nasional Pendidikan Dan Pembelajaran) 3. Kediri: UNP Kediri

Sholikhah, M. 2019. Speaking Skills and Critical Thinking Skills Development Through Project Based Learning method of EFL Tertiary Students. SELL Journal, (4) 2 78-98

Trihanifa. 2013. Siswa Sebagai Subyek Belajar. Diakses pada 11 November 2020 https://trihanifa.blogspot.com/2013/07/trial-1.html

Yulia, Y. \& Budiharti, S. R. 2019. HOTS in Teacher Classroom Interaction : A Case Study. Journal of English Education, Literature, and Culture, 4(2) 132-141

Zubaidah, S. 2018. Keterampilan Abad Ke 21 : Bagaimana Membelajarkan dan Mengaksesnya. National Conference of Tantangan Biologi dan Pendidikan Bilogi Abad-21. Riau : Pendidikan Biologi FKIP Universitas Islam Riau Zubaidah, N. 2020. Keterampilan Pembelajaran Abad-21 Disiapkan untuk Bonus Demografi. Koran Sindo, 23 Oktober 2020. Jakarta 